\title{
Causes and Consequences of the Academic Migration from BRICS Countries to Developed Economies
}

\author{
Bela Khakhuk ${ }^{1 *}$, Natalia Morgunova ${ }^{2,3}$, Lydia Nosenko ${ }^{4}$, Lyudmila Posokhova ${ }^{5}$ and Elena \\ Zatsarinnaya ${ }^{6}$ \\ ${ }^{1}$ Kuban State Technological University, Krasnodar, Russian Federation \\ ${ }^{2}$ Pacific National University, Khabarovsk, Russian Federation \\ ${ }^{3}$ Far Eastern State Transport University, Khabarovsk, Russian Federation \\ ${ }^{4}$ Federal State Budgetary Educational Institution of Higher Education "Orenburg State University", \\ Russian Federation \\ ${ }^{5}$ Sochi State University, Russian Federation \\ ${ }^{6}$ Plekhanov Russian University of Economics, Moscow, Russian Federation \\ khakhukbela@rambler.ru \\ morgonv@mail.ru \\ lidiano@list.ru \\ phd2003@mail.ru \\ e29175z@yandex.ru
}

\begin{abstract}
One of the major problems in the relationship between the Global South and the Global North is the the drain of intellectual capital from the economies and education systems of the most developed countries of the Global South, which bothers both developing countries and some European ones. The purpose of the study is to reveal the reasons for the migration of scientists and students from Brazil, the Russian Federation, India, China, South Africa (BRICS countries) and identify the consequences of the process through the example of a Russian university by studying the characteristics of personal experience and motivation of students and teachers. The research is devoted to the study of academic activity abroad and the attitude of 360 four- and five-year students and 321 teachers at Novosibirsk State University (Novosibirsk, the Russian Federation) towards the practice. The survey results revealed that a relatively small number of respondents (31.07\% of teachers and $9.03 \%$ of students) have experience of foreign academic activity; the large majority of participants highly assessed the possibility of studying and working abroad (4.87 and 3.48 on a 5-point Likert scale among teachers and students, respectively). The results of the study are in line with the findings of similar studies on academic migration in other BRICS countries; therefore, they can be extrapolated in a broader context. In particular, according to all respondents, the possibility of repeated or circular migration is extremely low $(0.88$ and 1.61$)$. The research results can help to manage international research and exchange programs, as well as to regulate university training programs and academic migration. The novelty of the study lies in the analysis of the motivation of scientists and students on academic migrating and their assessment of migration intentions based on an example of a single educational institution and region.
\end{abstract}

Keywords: academic migration; BRICS; brain drain; foreign academic activity; global research; global South and North

\section{Introduction}

The phenomenon of international exchange and human capital flight has been studied for more than a decade as it significantly affects the development of national economies. One of the most important events in the global political and economic life was the rapid development of countries that traditionally belonged to the third world and their achievement of several key economic indicators that are close to those of the most developed economies (Wolhuter and Chigisheva, 2020). This fact was recognized by Western researchers and described in Building Better Global Economic BRICs - an analytical report made by Goldman Sucks in 2001 which projected that the group of countries including Brazil, India, China and the Russian Federation would exceed the economic growth rates of the $\mathrm{G} 6$ countries until 2050. Some years later, as a result of another analytical response from the Goldman Sucks Group, South Africa was also joined to these countries. Thus, the concept of BRICS as a kind of unique group of countries with advanced indicators of economic growth emerged (Sebri and Dachraoui, 2020).

In fact, some researchers almost immediately after the BRICS (Brazil, the Russian Federation, India, China, South Africa) acronym introduced by Goldman Sacks analytics became widespread in academic research and media indicated that this term reference was completely speculative, not supported by any serious calculations and described it as an emotional perception of global changes in transnational trade and capital movement rather than a sound concept (Horvath and Carpenter, 2020; Wolhuter and Chigisheva, 2020). It was noted that the 
selection conditions for the formation of the group of BRICS countries violate the rules of a sufficient logical basis for classification, because there is not a single parameter that would unite all these countries. BRICS countries have different levels of GDP growth, different scale and structure of the economy, level of political participation or influence on their regions, different population sizes, etc. The expectation that the economies of these countries will overtake the $\mathrm{G} 6$ level by 2050 can also be extended to other rapidly developing countries (Sebri and Dachraoui, 2020; Wolhuter and Chigisheva, 2020; Secundo et al., 2020). Indonesia, South Korea, and some African countries could have been included in the group of undoubted leaders of economic and social development. It seems that the expert selection for the BRICS group was carried out based on the number of people (43\% of the world's population in 2016) and the size of the territory, which contributes to their national economy. The second significant selection criterion was the abundance of natural resources concentrated in these countries (Müller, 2020; Sebri and Dachraoui, 2020).

At the same time, all BRICS countries belong to the Global South - these are countries with developing or transitional economies as opposed to the Global North, which involves countries of the traditional colonial metropolis with the highest level of economic development, social security and military potential (Horvath and Carpenter, 2020; Müller, 2020). One of the major problems in the relationship between the Global South and the Global North is the brain drain from the economies and education systems of the most developed countries of the Global South, which bothers both developing countries and some European ones, such as Italy (Cattaneo, Malighetti and Paleari, 2019; Gupta, 2018; Ilić and Milosavljević, 2017). Brain drain involves the loss of both intellectual capital and human potential, and the investment in education that feeds the more advanced economies. Researchers note that all BRICS countries, as well as almost all countries of the Global South, are affected by the consequences of brain drain.

However, the problem of migration of highly skilled labor and intellectual capital is not unambiguous. Researchers point out that actually there is an effect of reverse transmission: migrants returning to their homeland bring new knowledge, methods of learning and work, and technologies; while working abroad, they generate huge cash flows that become a solid part of the investment potential for their home countries, and as a diaspora abroad, they create economic and socio-political support for their home countries (Bailey and Mulder, 2017; Dragan and Milosavljevic, 2018; Korobkov, 2020).

Hereinafter, "academic" refers to persons who study, teach, or do research at universities or public research centers, such as research institutes and institutes of national academies of sciences in post-Soviet countries or China. In all cases, to refer to certain groups of this category, such as teachers, students or scientists, they will be mentioned separately.

Most studies on intellectual migration are focused on scientists, students, and teachers from China; there is less research devoted to the situation in Brazil and India, and the problems of intellectual migration are insufficiently studied in the Russian Federation and South Africa (Novgorodtseva and Belyaeva, 2020; Tarasyev and Agarkov, 2019). At the same time, the researchers note that the features of the migration process of highly skilled labor and intellectual capital can be better understood if there is a wide range of field studies conducted in educational institutions and training centers, as well as in individual regions and countries (Gui, Liu and Du, 2019; Kubota, 2020).

In addition, most of the research in this area has been carried out on the basis of qualitative methodology: selected unstructured interviews, analysis of individual experience, analysis of individual or group discourse on the exchange of scientists from certain countries, etc. (Cattaneo, Malighetti and Paleari, 2019; Dragan and Milosavljevic, 2018; Leung, 2017; Wang, 2020). The research proposed in this article is quantitative and intends to encourage researchers to conduct measurable studies in the field of the flow and transfer of intellectual resources and the features of these processes, as well as their impact on individual economies and the global economy. In addition, this study, in contrast to those listed below, focuses on the individual experience of academics, as the central agents of both intellectual capital management processes and academic migration. It is the factors of personal motivation and intentions, according to researchers, that reflect the trends of academic migration most fully and can be used for predicting and further factor analysis of this process in quantitative research (Vangen, C., 2016; Van Holm, Wu and Welch, 2019; Tarasyev and Agarkov, 2019; Miguelez and Temgoua, 2020).

The study aims to contribute to the research in this area based on the examination of a Russian university. The purpose of the study is to reveal the reasons for the migration of scientists and students from BRICS countries 
and identify the consequences of the process through the example of a Russian university by studying the characteristics of personal experience and motivation of students and teachers. The novelty of this study lies in the analysis of the motivation of scientists and students for academic migration and the assessment of migration intentions based on a survey of a single educational institution and region (Novosibirsk State University, the Russian Federation). The study also aims to fill the gap related to the insufficient quantitative research on academic migration.

\section{Literature review}

The phenomenon of academic migration from BRICS countries is obviously large-scale, and it does not lend itself to accurate statistics and qualifications (Chang, Chen and Xiong, 2018; Leskina et al., 2020; Wolhuter and Chigisheva, 2020). Researchers point out that the academic community, including scientists, teachers and students, tend to migrate by means of business travel, tourist visas and other methods rather than by accepted or fixed routes (Rostovskaya et al., 2020). Therefore, according to researchers, the statistics of academic migration provided by officials, in particular in the Russian Federation, cannot be considered adequate (Kosyakov and Guskov, 2019; Tarasyev and Agarkov, 2019).

At the same time, the migration movement is ambiguous. In the past five years, studies conducted in China, India or Brazil have shown that there are three migration flows: a flow from the Global South to the Global North, a return flow to participate in national science programs, and a circular or repeated migration (Bailey and Mulder, 2017; Dick and Duchêne-Lacroix, 2016). Thus, there is a loss of skilled workers seeking a higher standard of living, available technologies, and research opportunities; however, there is a reverse process that involves the transfer of acquired technologies and knowledge to the homeland (Bouabid, Paul-Hus and Larivière, 2016; Vangen, 2016).

One of the complex research topics is assessing the quality of the intellectual potential of the BRICS member countries and its role in migration. Some researchers point out that the countries of the Global North are in the phase of both economic and academic stagnation, and the quality of education and training is declining; in particular, this refers to secondary education (Miao and Wang, 2017). Therefore, it is important to attract intellectual resources from abroad in order to maintain high-tech society and manufacturing (Bouabid, Paul-Hus and Larivière ,2016; Horvath and Carpenter, 2020). Replenishment of intellectual capital is critical for maintaining the sustainable competitive development of both large and small and medium-sized businesses, which are an important part of the economies of most developed countries (Bryl and Fijałkowska, 2020; Secundo et al., 2020). On the other hand, there are studies that indicate that higher level of technology, as well as the better quality of education, research and academic programs in developed economies, attract students and scholars from the Global South (Faist, 2018; Leskina et al., 2020; Miguelez and Temgoua, 2020).

A serious problem generated by the outflow of intellectual resources from the BRICS countries is the decrease in the investment attractiveness of sending countries, while the cash flows that migrants return to their homeland stimulate consumption, in particular, exports of goods and services from the countries migrants leave for, rather than investment in infrastructure or human capital (for example, in education). Thus, the countries of origin of migrants remain resource donors and consumption markets (Chang, Chen and Xiong, 2018). It should be noted that in different BRICS countries the situation varies dramatically; in particular, in China, where the domestic market is largely dominated by national products and technologies, while other BRICS countries are large commodity importers (Dall'agnol et al., 2019; Solimano, 2016).

The problem of academic mobility is a serious issue. Academic mobility is becoming one of the major factors of social stratification and an important factor in the development of knowledge management processes in universities and international research centers that attract scientists from different countries (Va Van Holm, Wu and Welch, 2019; Vătămănescu et al., 2019). In this regard, an important question regards the distribution of the products of the intellectual capital accumulated in such research centers and the return of the financial results of the activity of this intellectual capital to the homelands (lacuzzi, Massaro and Garlatti, 2020; Secundo et al., 2020). Thus, the ability to cross national borders and study abroad is a determinant of a high position in the academic community; however, at the same time, migrants most often experience "downward social mobility" (Leung, 2017). The phenomenon used to be viewed as an exclusively positive issue in relation to migrants while in fact it brings them traumatic and uncertain results. 
Modern researchers are shifting from the term "brain drain" as not corresponding to reality and come up with parallel terms, such as "brain gain" and "brain sharing" (Gurieva, 2016; Rostovskaya, Pismennaya and Skorobogatova, 2018). The latter is related to the fact that academic mobility in a digital society may not be associated with real geographic movement as the scientist continues to work in their country. Some scholars have a rather revolutionary view of academic transfer and mobility which they describe as a temporal rather than spatial phenomenon as it is associated with a different period of life rather than movement (Wang, 2020).

Several studies indicate that the motivation and intention of academics are the primary factor of academic migration, and analyze cross-sections of the economic, political and psychological elements of this process (Vangen, 2016; Volokh and Gerasimova, 2019; Wang, 2020). Research based on interviews with academic migrants also emphasizes the problem of motivation; studies from across the global South indicate that these motivations have much in common across regions (Leung, 2017; Van Holm, Wu and Welch, 2019; Novgorodtseva and Belyaeva, 2020). However, direct research into the motivation of academic migration using representative surveys and quantitative methodology is lacking (Ilić and Milosavljević, 2017; Gui, Liu and Du, 2019; Korobkov, 2020).

\section{Material and Methods}

The study was conducted at Novosibirsk State University (Novosibirsk, the Russian Federation) in November 2020 with the participation of 360 four- and five-year students (graduates) studying humanitarian and natural sciences. The confidence interval of $5 \%$ for the general population of the students studying at the university, the sample provides reliable results. There were 185 men and 175 women aged $22-29$ years involved in the experiment.

The second group of respondents - teachers of the same university - involved 321 people. There were 171 men and 150 women aged 31-64 years. Under the same conditions, the sample is representative and the results of the survey provide statistically significant results.

The participants were invited to participate in the study on a voluntary basis and were informed of both the objectives and methods of the research. Each participant received an electronic (by email) or a physical copy of the questionnaire with a unique random number, which guaranteed the confidentiality of participation. No personal information was collected or used during the study.

Based on the data obtained, we studied the percentage of responses and calculated the Spearman's rank correlation coefficient between some answer options and groups of participants by gender, age and specialization (natural science or humanitarian) to identify dependencies. Spearman's rank correlation coefficient was used since we used ordinal data in this test, not continuous data.

The survey questions were selected based on the features of foreign research on this issue over the past 5 years (Bailey and Mulder, 2017; Cattaneo, Malighetti and Paleari, 2019; Leung, 2017; Wang, 2020). The assessment was based on a 5-point Likert scale, where 1 is a slight agreement or complete disagreement with the statement, and 5 - complete agreement with the statement. In the statistical processing and visualization of the results, the arithmetic mean of the estimates for each answer option was used. To study the Spearman's rank correlation coefficient, we relied on the aggregates of the responses given by the participants for each answer option rather than on their mean values. It should be considered that the respondents may have simultaneously referred themselves to several groups as they have experience of different types of academic activities abroad.

The test used for this study was developed by the author on the basis of research. This pilot study serves as a reference for the subsequent more accurate verification of the validity of this text. Reliability of the test was checked using Cronbach alpha and got a high enough score: $\alpha=.716$. The validity of the study was confirmed by a special additional survey of study participants, who were asked to assess whether the content of the questions and assessments of the test offered to them corresponds to the content of the object under study. Confirmation was received from all study participants.

When interviewing students and teachers, the question was focused on both the intention to take part in international interaction and work and the real experience of this kind. In the study, the real experience is reflected by two indicators: the percentage of the number of respondents with relevant experience and the 
subjective assessment of the experience based on the Likert scale ("positive/negative" or "I want to do this again/I do not want to do this again."

The research results were processed in SPSS 22.0 and visualized in MS Excel 2013.

\section{Results}

Figure 1 shows the respondents' assessment of their desire to take part in certain academic activities abroad. It should be noted that in this case, the assessment refers not only to the experience but also to the general intention to participate. The desire to take part in international academic programs ( 4.87 points by students and a slightly more cautious estimate of 3.48 points by teachers) and get a job in commercial companies related to the academic activity ( 4.19 and 4.47 , respectively) prevail. In the second case, the teachers gave a higher assessment due to the obviously greater experience and confidence in their capabilities when working for commercial organizations.

\section{Assessment of the respondents' own intentions regarding foreign academic activity}

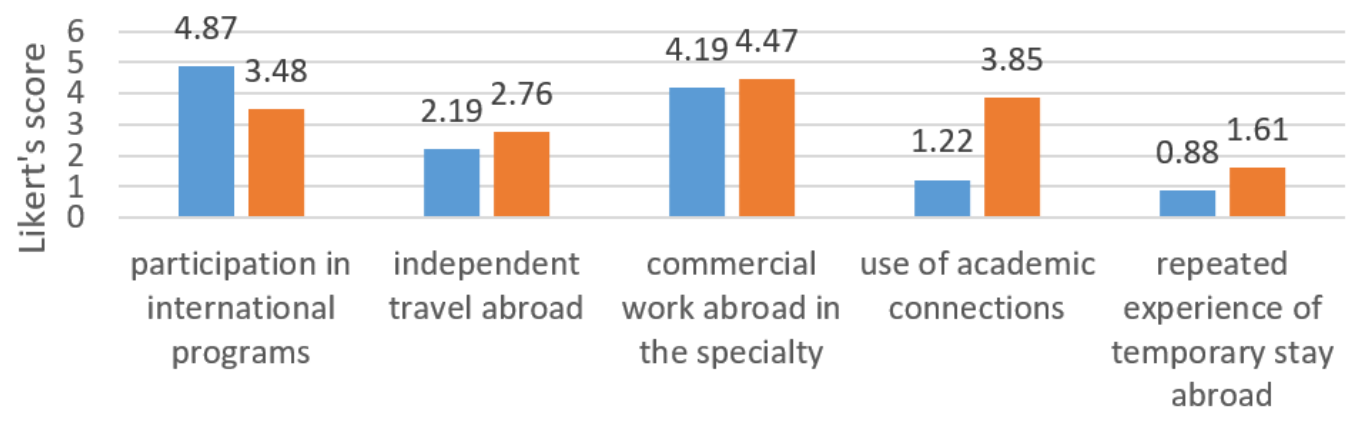

\section{Activities}

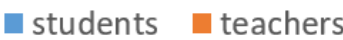

Figure 1: The respondents' intentions to conduct foreign academic activities

The possibilities of independent travel abroad to implement some plans of academic development received a lower assessment. Nevertheless, the assessment of independent activity in this direction is unexpectedly high (2.19 and 2.76, respectively). Both groups of participants gave the lowest assessment to the possibility of the multiple use of the experience of studying or working abroad - 0.88 and 1.61, respectively. The teachers and researchers naturally demonstrated much greater enthusiasm in the assessment of the possibility of using academic connections to go abroad for academic purposes compared to students who have not established such connections yet (3.85 and 1.22 , respectively).

Figure 2 shows the percentage of respondents who have real experience of certain academic activities abroad. In the sample, there were no students who had acquired a scientific degree abroad or built an academic career abroad. The number of teachers with such experience also turned out to be low (Figure 2). There are also very few of those who continue their research abroad (8.12\%), and it is natural that there are very few of them among students $(0.18 \%)$; as a rule, these are the participants in international programs or holders of certain academic grants. At the same time, up to a third of the teachers and scientists surveyed either have work experience abroad or plan to continue this experience (31.02\% and $31.07 \%$, respectively). There are extremely few students in this category. Despite the fact that there is a rather noticeable part of students who also have such experience (5.28\% and $9.03 \%$, respectively), it is obvious that there is no real basis in the form of experience for the positive expectations of commercial work related to academic interests abroad (Figure 1). 


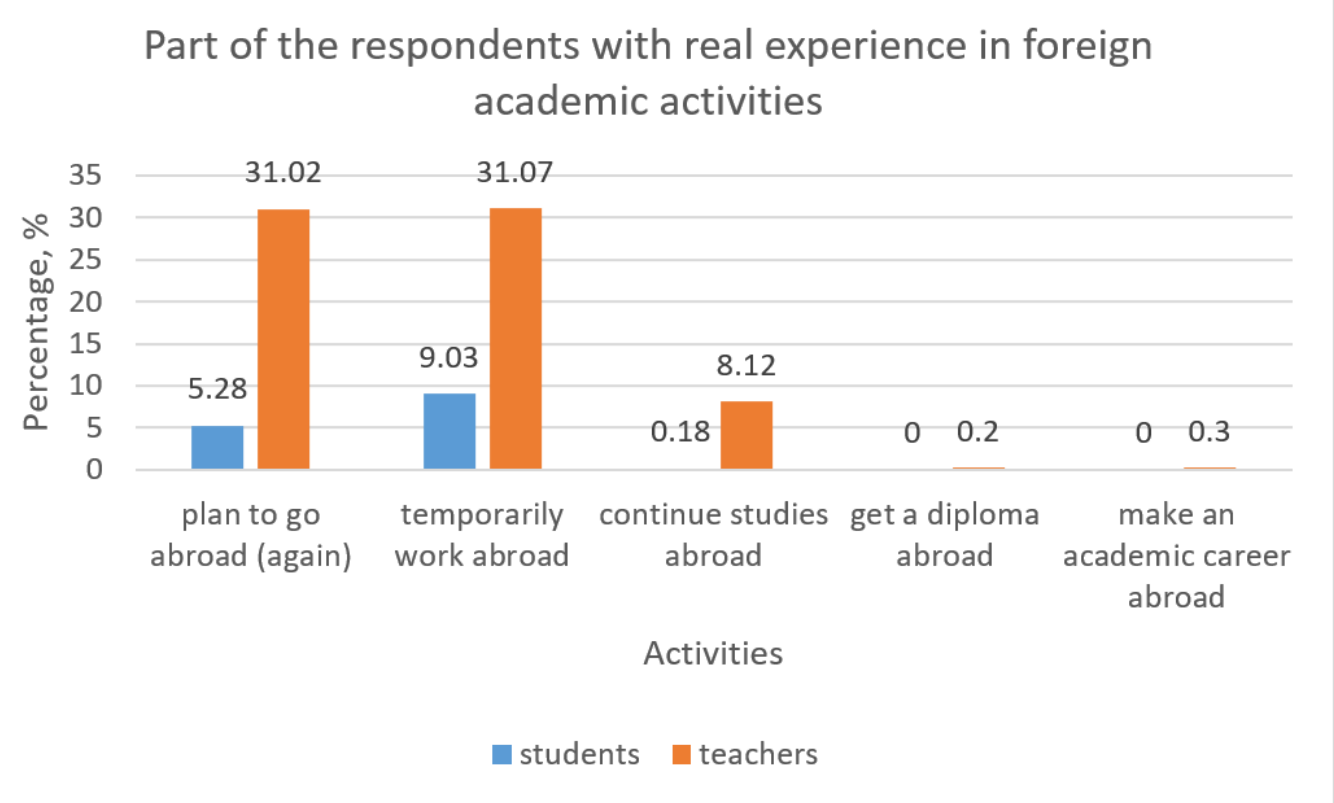

Figure 2: The respondents with real experience of foreign academic activities

Figure 3 shows the respondents' assessment of their own experience of foreign activities; it is a very important fact that it almost coincides with the estimates given by the relative percentage of those who have such experience. In general, according to students, academic experience abroad was assessed as low; apparently, this is due to their lack of involvement, lack of information about academic connections, and relatively little interaction with them. The sample may have included mainly those who did not have high achievements as a result of such experience, which may be a manifestation of sampling bias; however, this is unlikely due to the statistical reliability of the sample.

The teachers gave a high assessment to the possibility of going abroad again and conducting temporary academic activities abroad. However, their assessment can be described as rational and positive rather than overestimated (3.48 and 3.17, respectively).

\section{Respondents' assessment of their own experience of foreign academic activity}

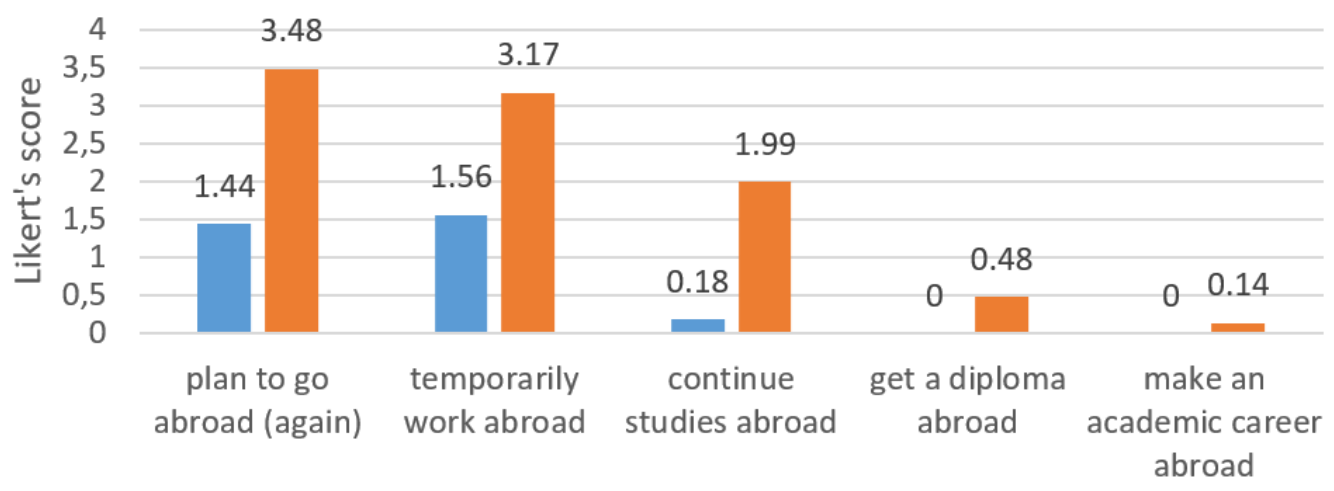

Activities

ustudents $\mathbf{\text { teachers }}$

Figure 3: Respondents' assessment of their experience of foreign academic activities 
Figure 4 shows the percentage of respondents who have certain experience of academic work, education and other types of academic activity abroad by groups. There are very few of them among students. There are $17.82 \%$ of those students who take part in some kind of international academic programs, including student exchange programs, etc. This is the highest indicator among students. The number of teachers in this group of respondents is also the highest (74.82\%). The percentage of those who tried to get a job abroad in an academic environment or in commercial organizations on their own with the help of academic connections is approximately at the same level and ranges from $12.86 \%$ to $16.95 \%$.

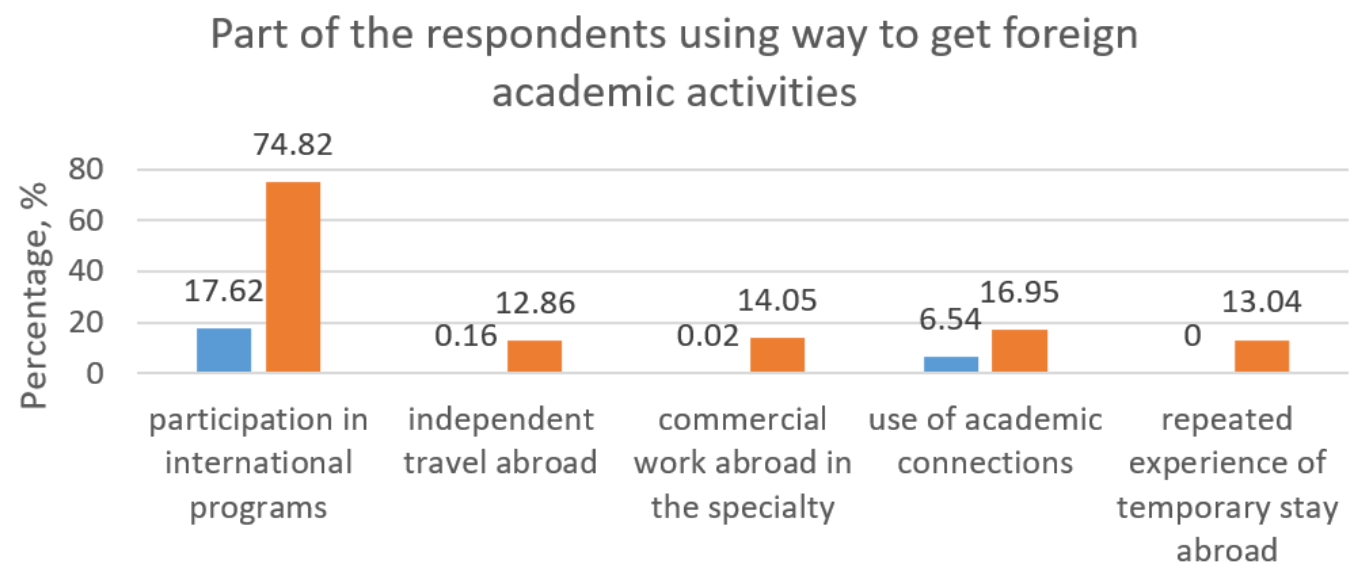

Activities

atudents teachers

Figure 4: Percentage of respondents who have the experience of academic activities abroad

Figure 5 demonstrates the respondents' assessment of different ways of gaining access to academic activity abroad. The teachers and researchers assigned the highest points to the use of their own academic connections (4.15) and the work in the commercial sector in the field of specialty (4.12); a slightly lower assessment was also given to the participation in international programs (3.11). The possibility of independent travel and the experience of traveling abroad and being "suspended" for a long time are negatively assessed and given extremely low points (1.02 and 1.85 , respectively).

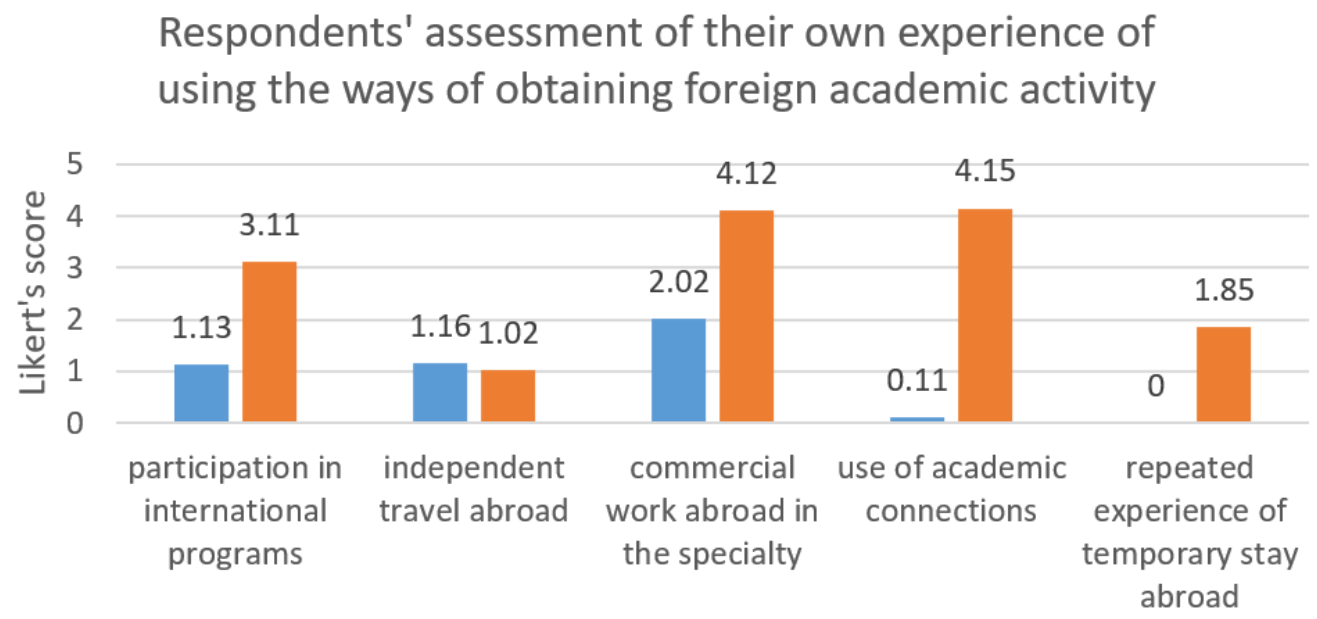

Activities

a students $\square$ teachers

Figure 5: Respondents' assessment of the ways to get the experience of foreign academic activity 
The assessment of the experience by students seems to be clearly overestimated based on unreasonable expectations in comparison to previous indicators. Thus, 4.15 for the use of academic connections is the assessment of the experience by teachers - students tend to draw their own conclusions based on teacher experience rather than their own. At the same time, the possibility of independent attempts to get a job abroad in the academic field is also rated low by students (1.16).

For reasons of space, we will describe only those Spearman's rank correlation coefficients $(\rho)$ that have values according to current research practice estimated as an average or high correlation coefficients, that is, above $\rho$ $\geq 0.35$. The indicator was selected based on global experience and the fact that most of the ratios of the values in the study turned out to be below the threshold. Full information on correlations is presented in the Appendix (Tables 1-3).

First of all, it should be noted that the study did not reveal any significant correlations related to gender characteristics. No correlations that exceeded the threshold in relation to the group of students were found. A more detailed study of statistical data gives some grounds to assert that this result is largely associated with the relatively poor involvement of students in real academic activity abroad and the heterogeneity of such experience and its assessment in their environment. It seems that this issue requires a more thorough further assessment and research.

There were also almost no significant correlations found between the estimates and age categories. Weak correlations were found between the use of academic connections abroad to conduct academic activities and the 50-60 age group ( $\rho=0.3587$ for real experience and $\rho=0.4102$ for intension only) and the over 60 age group ( $\rho=0.5817$ for real experience and $\rho=0.6781$ for intension only). This is quite natural and is associated with the experience and accumulated connections of people with extensive academic experience. A correlation between the possibility of academic activity abroad through commercial employment in the specialty and the 40-50 age group ( $\rho=0.4119$ for real experience and $\rho=0.3912$ for intension only) was also revealed; however, the correlation is not strong enough.

Based on this approach, the stronger correlations should be noted. The strongest correlation was found between the group of those who had real experience in connection with academic interests in commercial companies abroad and the representatives of natural sciences ( $\rho=0.6891$ for teachers and $\rho=0.7102$ for students), as well as between participation in international programs and the representatives of humanitarian specialties $(\rho=$ 0.5415 for teachers and $\rho=0.592$ for students). These correlations indicate the logic of the distribution of the interests of both researchers and foreign institutions that attract them or tend to attract them to participate in international activity.

\section{Discussion}

It should be noted that the research results are fully consistent with the results obtained by researchers from other countries based on the analysis of the personal experience of individuals, interviews, and other methods. Principally, the survey results indicate the presence of the same trends in the Russian Federation and other BRICS countries, which demonstrates the possibility of extrapolating the research results both to other educational institutions and other countries of the region.

Thus, according to Chinese researchers, one of the major problems of young scientists is the so-called repeated migration or circular migration, which includes those who try to build a scientific career in the countries of the Global North but cannot live and work there permanently (Teplyakov and Teplyakova, 2018). The main problem of researchers and students from China and India who try to build their careers in this way is the shock of social displacement. In the homeland most of them belong to the middle class or upper middle class; when they move, they significantly lower their social status and spend a lot of time and effort to take a more worthy position without a guarantee that they will achieve success (Chellaraj, 2019; Faist, 2018; Rostovskaya, Pismennaya and Skorobogatova, 2018). Significant intellectual migration rates have led to the fact that there is rather fierce competition for jobs in universities and research centers of the Global North, and various forms of temporary employment of scientific personnel have been common for a decade (Chang, Chen and Xiong, 2018; Wang, 2020). This also led to the class stratification in the academic environment - there are permanent employees (post-doctoral students, adjuncts, teachers having a permanent contract) and the "lower" class of temporarily employed research workers (Solimano, 2016). Due to the circular nature of migration in China, this has led to 
the fact that a number of young scientists and teachers are also temporary workers in their homeland, which creates "permanent temporality" with special psychology, characteristics of the division of labor and specific social connections (Ivenicki, 2020). In our research, both the possibility of circular migration and the experience of repeated trips were given low points by all groups of participants and were not included in the expectations or intentions of the respondents. Due to the fact that this issue has not been considered separately in detail and requires further studies, it can be concluded that the phenomenon of circular migration and its negative consequences are also characteristic of the Russian Federation as such a pronounced negative attitude can be formed only on the basis of a certain common experience (Antoshchuk and Ledeneva, 2019).

According to almost all researchers, a higher standard of living, protection from unstable political and economic situation in the home country, a higher income, and wider access to the experimental base and opportunities for contact with colleagues are the reasons for the migration of scientists and students (Dwyer, 2018). Our research also confirms these findings as it is the opportunity to work for commercial companies based on the academic experience that is the most precious experience of academic activity and is included in the plans and intentions of all groups of respondents with the highest scores.

Several researchers note that the social connections and the processes of introduction of foreign researchers to the workplace environment play a significant role in the characteristics of scientific migration (Bouabid, PaulHus and Larivière, 2016). The most extensive data have been accumulated on Chinese migration and, to a lesser extent, on Indian and Brazilian migration; there is almost no structured information about the academic migrants of South Africa and the Russian Federation. A common problem is the more laborious integration into the networks of mutual assistance and contacts characteristic of the Global North and the development of closed networks of support and data exchange by the representatives of the scientific Global South, which are largely tailored to their interests. It is known that Chinese migrants prefer to concentrate on work and demonstrate higher productivity compared to their Western counterparts, but they have much more limited access to the resources and research opportunities that open through academic connections (Antoshchuk and Ledeneva, 2019; Ivenicki, 2020).

When people arrive in another country or stay there for a long time, they experience a certain culture shock and lack of social contacts (Vangen, 2016). Moreover, researchers indicate that this is associated with the intellectual and social barrier rather than the language barrier. At the same time, migrants note a generally very positive attitude towards them on the part of the Global North residents, and the absence of xenophobia or aloofness (Van Van Holm, Wu and Welch, 2019). This contributes to the formation of closed scientific diasporas and the return transfer of scientists to their homeland. Most BRICS countries implement special programs designed to stimulate the return of scientists and students to their homeland (Korobkov, 2020; Volokh and Gerasimova, 2019; Zvereva, Belenkova and Kruse, 2020). China has made the greatest efforts in this regard since the late 1990s (Miao and Wang, 2017).

In our study, the respondents also indicated they expect a low chance of permanent stay abroad and a relatively moderate chance of repeated trips, which may also show a not fully positive assessment of their personal experience. At the same time, most participants also rated the expectation of establishing an academic career abroad as low, except for those who have already had such experience or are trying to implement it. This confirms the results of other studies of academic migration from BRICS countries which also noted a low percentage of implementation of career aspirations in the countries of the Global North among those who are trying to do this (Antoshchuk and Ledeneva, 2019). Monopolization of knowledge, access to resources, and publishing monopoly, which limits access to the ability to publish research, were cited as the most important reasons (Collyer, 2018; Tripathi et al., 2018). Similarly, Chinese researchers had collected the opinions of Chinese and Indian scholars, who described the monopolization of methodology and presentation of scientific research in accordance with the intellectual tradition adopted in the West, which greatly limited the possibilities of their colleagues from the Global South (Chellaraj, 2019).

\section{Conclusion}

According to most foreign studies and the results of the present research, the most significant motivation for academic migration is the expectation of higher incomes, social protection, and access to opportunities for academic development. There is a large gap in the quantity and quality of research on academic migration from the BRICS countries to countries of "global North". The study illustrates the findings of quantitative research on 
academic migration focusing on the Russian experience in the context of the more common problems and trends that characterize all BRICS countries. The results obtained are in line with those of similar - predominantly qualitative - studies on academic migration from other BRICS countries, which makes it possible to extend the validity of the results to a more general level. The survey based on the 5-point Likert scale revealed that a small number of respondents (31.07\% among teachers and $9.03 \%$ of students) have real experience of academic migration in its various forms while the overwhelming majority highly assess the academic opportunities abroad ( 4.87 and 3.48 among teachers and students, respectively). Much of the motivation of both groups was focused on the opportunity to work in the commercial sector due to their academic activity (4.19 and 4.47, respectively). In particular, according to all respondents, the possibility of repeated or circular migration is extremely low $(0.88$ and 1.61). The novelty of the study is its quantitative nature and the focus on the Russian experience, which has not been studied earlier. Including the Russian experience into the broader picture of academic migration from BRICS countries will make it possible to draw much more accurate conclusions and recommendations for the future. A practical contribution of the study is the provision of insights into the issue, which can be useful for setting policies to regulate academic migration. In particular, enhancing the development of loyalty programs for students and academic workers can be suggested, as well as the implementation of national academic employment programs.

The limitations of the research are related to the fact that the study is based on the example of one Russian university and involves graduates of two senior years of study. Also, it does not consider differences in the nationality of the respondents, their socio-economic status, the connections with institutions, relatives, business contacts or friends abroad, etc. Also, the study does not differentiate between separate academic fields, for example, medicine or engineering sciences, etc., within which the motivations for migration can differ significantly.

\section{Funding}

This research received no specific grant from any funding agency in the public, commercial, or not-for-profit sectors.

\section{Conflicts of interest}

The authors declare that there are no conflicts of interest related to this article.

\section{References}

Antoshchuk, I. and Ledeneva, V.Y., 2019. From Russia to the UK. On migration mechanism of young Russian computer scientists. Sociological Sstudies, 2, pp 108-118. https://doi.org/10.31857/s013216250004015-9.

Bailey, A. and Mulder, C.H., 2017. Highly skilled migration between the Global North and South: gender, life courses and institutions. Journal of Ethnic and Migration Studies, 16, pp 2689-2703. https://doi.org/10.1080/1369183x.2017.1314594.

Bouabid, H., Paul-Hus, A. and Larivière, V., 2016. Scientific collaboration and high-technology exchanges among BRICS and G-7 countries. Scientometrics, 106(3), pp 873-899. https://doi.org/10.1007/s11192-015-1806-0.

Bryl, Ł. and Fijałkowska, J., 2020. How does intellectual capital disclosure affect the cost of capital? Conclusions from two decades of research. Electronic Journal of Knowledge Management, 18(1), pp 29-55. https://doi.org/10.34190/EJKM.18.01.003

Cattaneo, M., Malighetti, P. and Paleari, S., 2019. The Italian brain drain: cream and milk. Higher Education, 77(4), pp 603622. https://doi.org/10.1007/s10734-018-0292-8.

Chang, V., Chen, Y. and Xiong, C., 2018. Dynamic interaction between higher education and economic progress: a comparative analysis of BRICS countries. Information Discovery and Delivery, 46(4), pp 225-238. https://doi.org/10.1108/idd-07-2018-0023.

Chellaraj, G., 2019. The economics of international student and scholar mobility: Directions for research. Washington DC: The World Bank.

Collyer, F.M., 2018. Global patterns in the publishing of academic knowledge: Global north, global south. Current Sociology, 66(1), pp 56-73. https://doi.org/10.1177/0011392116680020.

Dall'agnol, M., Ferraz, D., Costa, N.D., Moralles, H.F. and Rebelatto, D.A.D.N., 2019. R\&D spillovers from international student flows: a BRICS analysis. Production, 29, pp e20190054. https://doi.org/10.1590/0103-6513.20190054

Dick, E. and Duchêne-Lacroix, C., 2016. Multi-local living in the global south and global north: Differences, convergences and universality of an underestimated phenomenon. Trialog, 116(1-2), pp 4-9.

Dragan, I.L.I.C. and Milosavljevic, M., 2018. Brain drain: Propulsive factors and consequences. Journal of Economic Development, Environment and People, 6(4), pp 29-40. 
Dwyer, T., 2018. Empirical studies of youth in contemporary Brazilian civilization and some implications for the BRICS. In: T. Dwyer, M.K Gorshkov, I. Modi, C. Li and M.S. Mapadimeng, (eds). Handbook of the Sociology of Youth in BRICS Countries. Singapore: World Scientific Publishing. pp 841-860.

Faist, T., 2018. The transnationalized social question: Migration and the politics of social inequalities in the twenty-first century. Oxford: Oxford University Press.

Gui, Q., Liu, C. and Du, D., 2019. Globalization of science and international scientific collaboration: A network perspective. Geoforum, 105, pp 1-12. https://doi.org/10.1016/j.geoforum.2019.06.017.

Gupta, N., 2018. An analysis of higher education system in Brics nations and its economic potential. 14th UPUEA Economic Journal, 14, pp 329-333.

Gurieva, L.K., 2016. The role of intellectual work migration in solving the problems of competitive economy development. Science Almanac of Black Sea Region Countries, 1(5), pp 30-33.

Horvath, C. and Carpenter, J., 2020. Co-creation in theory and practice: Exploring creativity in the global north and south. Bristol: Policy Press.

lacuzzi, S., Massaro, M. and Garlatti, A., 2020. Value creation through collective intelligence: Managing intellectual capital. Electronic Journal of Knowledge Management, 18(1), pp 68-79. https://doi.org/10.34190/EJKM.18.01.005

Ilić, D. and Milosavljević, M., 2017. Brain drain: Propulsive factors and consequences. Journal of Economic Development, Environment and People, 6(4), pp 2285-3642. https://doi.org/10.26458/v4.i1.22.

Ivenicki, A., 2020. Multicultural Brazil in the BRICS Countries: Potentials for the social sciences and humanities. Space and Culture, India, 7(5), pp 14-22. https://doi.org/10.20896/saci.v7i5.641.

Korobkov, A.V., 2020. Russian academic diaspora: its scale, dynamics, structural characteristics, and ties to the RF. In: M. Denisenko, S. Strozza and M Light, (eds.) Migration from the newly independent states. Cham: Springer. pp 299-321.

Kosyakov, D. and Guskov, A., 2019. Impact of national science policy on academic migration and research productivity in Russia. Procedia Computer Science, 146, pp 60-71. https://doi.org/10.1016/j.procs.2019.01.080.

Kubota, L.C., 2020. BRICS cooperation in science, technology and innovation: progress to be shown. Revista Tempodo Mundo, 22, pp 95-110.

Leskina, O., Barbashova, S., Burmistrova, O. and Mochalina, Y., 2020. Human potential and competitiveness of Russia in the context of the BRICS association. In: Ecological-Socio-Economic Systems: Models of Competition and Cooperation (ESES 2019). Paris: Atlantis Press, pp 479-482.

Leung, M.W., 2017. Social mobility via academic mobility: Reconfigurations in class and gender identities among Asian scholars in the global north. Journal of Ethnic and Migration Studies, 43(16), pp 2704-2719. https://doi.org/10.1080/1369183x.2017.1314595.

Miao, L. and Wang, H., 2017. Global talent migration: The barrier and breakthrough of foreign immigrants in China. In: Miao, L. and Wang, H (eds) International Migration of China. Singapore: Springer. pp 85-103.

Miguelez, E. and Temgoua, C.N., 2020. Inventor migration and knowledge flows: A two-way communication channel? Research Policy, 4(9), pp 103914. https://doi.org/10.1016/j.respol.2019.103914.

Müller, M., 2020. In search of the global east: Thinking between north and south. Geopolitics, 25(3), pp 734-755. https://doi.org/10.1080/14650045.2018.1477757.

Novgorodtseva, A.N. and Belyaeva, E.A., 2020. Internationalization of higher education in Russia: sociocultural interaction of students from the BRICS countries (Russia, China). Perspectives of Science and Education, 44(3), pp 517-526. https://doi.org/10.32744/pse.2020.3.37.

Rostovskaya, T.K., Manshin, R.V., Mekeko, N.M. and Knyazkova, E.A., 2020. Academic mobility as a factor of migration activity of students. Utopía y praxis latinoamericana: revistainternacional de filosofíaiberoamericana y teoría social, 5, pp 265-278.

Rostovskaya, T.K., Pismennaya, E.E. and Skorobogatova, V.I., 2018. Academic mobility of Russian scientists: from "brain drain" to "brain circulation" model. RUDN Journal of Economics, 26(4), pp 706-717. https://doi.org/10.22363/23132329-2018-26-4-706-717.

Sebri, M. and Dachraoui, H., 2020. Resources bless BRICS. MPRA Paper, pp 100423

Secundo, G., Ndou, V., Del Vecchio, P. and De Pascale, G., 2020. Sustainable development, intellectual capital and technology policies: A structured literature review and future research agenda. Technological Forecasting and Social Change, 153, pp 119917. https://doi.org/10.1016/j.techfore.2020.119917

Solimano, A., 2016. Global migration and international development in unstable times. International Center for Globalization and Development, Working paper, 25, pp 7. https://doi.org/10.1002/9781444351071.wbeghm520.

Tarasyev, A.A. and Agarkov, G.A., 2019. Modern tendencies of scientific migration in the Russian Federation. AIP Conference Proceedings, 2116(1), pp 200002. https://doi.org/10.1063/1.5114183.

Teplyakov, D. and Teplyakova, O., 2018. National policy for academic mobility in Russia and the BRICS countries: 20 years of the Bologna process implementation. BRICS Law Journal, 5(1), pp 5-26. https://doi.org/10.21684/2412-2343-20175-1-5-26

Tripathi, M., Jeevan, V.K.J., Babbar, P. and Mahemei, L.K., 2018. Library and Information Science research in BRICS countries. Information and Learning Science, 119, pp 183-202. https://doi.org/10.1108/ils-10-2017-0101.

Van Holm, E.J., Wu, Y. and Welch, E.W., 2019. Comparing the collaboration networks and productivity of China-born and US-born academic scientists. Science and Public Policy, 46(2), pp 310-320.

Vangen, C., 2016. "A decent life, a safe life": A mixed methods study of the motivations and challenges of students from the BRICS at UiO and NTNU. Master's thesis, University of Oslo. 
Vătămănescu, E.M., Gorgos, E.A., Ghigiu, A.M. and Pătruț, M., 2019. Bridging intellectual capital and SMEs internationalization through the lens of sustainable competitive advantage: a systematic literature review. Sustainability, 11(9), pp 2510. https://doi.org/10.3390/su11092510

Volokh, V. and Gerasimova, I., 2019. Management of migration processes in the Russian Federation: analysis and prospects. Management, 7(1), pp 5-12. https://doi.org/10.26425/2309-3633-2019-1-5-12.

Wang, B., 2020. Time in migration: temporariness, precarity and temporal labour amongst Chinese scholars returning from the Global North to South. Journal of Ethnic and Migration Studies, 46(11), pp 2127-2144. https://doi.org/10.1080/1369183x.2019.1642741.

Wolhuter, C. and Chigisheva, O., 2020. The BRICS countries grouping: Promise of a new thematic and methodological research focus in the social sciences and the humanities. Space and Culture, India, 7(5), pp 3-13. https://doi.org/10.20896/saci.v7i5.606.

Zvereva, E.V., Belenkova, N.M. and Kruse, I.I., 2020. From the economic union to the harmonisation of higher ducation in the BRICS countries: The experience of RUDN University. Space and Culture, India, 7(5), pp 60-69. https://doi.org/10.20896/saci.v7i5.671.

\section{Appendix}

Table 1: Spearman's rank correlation coefficient between some answer options and groups of participants by gender

\begin{tabular}{|c|c|c|c|c|}
\hline & \multicolumn{2}{|c|}{ students } & \multicolumn{2}{|c|}{ teachers } \\
\hline & male & female & male & female \\
\hline \multicolumn{5}{|c|}{ Respondents' assessment of their own experience of foreign academic activity } \\
\hline plan to go abroad (again) & 0.019 & 0.2347 & 0.2243 & 0.2114 \\
\hline temporarily work abroad & 0.2216 & 0.1875 & 0.2716 & 0.2618 \\
\hline continue your studies abroad & 0.2708 & 0.2672 & 0.291 & 0.2291 \\
\hline get / confirm a degree abroad & 0.3099 & 0.3081 & 0.3021 & 0.2601 \\
\hline make a scientific career abroad & 0.2619 & 0.2212 & 0.3211 & 0.1603 \\
\hline \multicolumn{5}{|c|}{ Assessment of the respondents' own intentions regarding foreign academic activity } \\
\hline participation in international programs & 0.2201 & 0.2812 & 0.2314 & 0.2433 \\
\hline independent travel abroad & 0.2416 & 0.1672 & 0.2709 & 0.2862 \\
\hline commercial work abroad in the specialty & 0.2093 & 0.2374 & 0.3102 & 0.2607 \\
\hline using your own academic connections & 0.2413 & 0.2768 & 0.2605 & 0.3099 \\
\hline experience of multiple temporary stay abroad & 0.2092 & 0.3033 & 0.3044 & 0.2806 \\
\hline \multicolumn{5}{|c|}{ Part of the respondents with real experience in foreign academic activities } \\
\hline participation in international programs & 0.2216 & 0.2334 & 0.2408 & 0.2684 \\
\hline independent travel abroad & 0.2619 & 0.2019 & 0.2474 & 0.3091 \\
\hline commercial work abroad in the specialty & 0.2809 & 0.3001 & 0.2134 & 0.2654 \\
\hline using your own academic connections & 0.2307 & $0 / 2161$ & 0.1904 & 0.1877 \\
\hline experience of multiple temporary stay abroad & 0.1887 & 0.2075 & 0.2264 & 0.2709 \\
\hline \multicolumn{5}{|c|}{ Part of the respondents using way to get foreign academic activities } \\
\hline participation in international programs & 0.1933 & 0.2316 & 0.2309 & 0.2219 \\
\hline independent travel abroad & 0.1418 & 0.2061 & 0.1673 & 0.1708 \\
\hline commercial work abroad in the specialty & 0.2109 & 0.2842 & 0.2375 & 0.2463 \\
\hline using your own academic connections & 0.189 & 0.1901 & 0.2106 & 0.2277 \\
\hline experience of multiple temporary stay abroad & 0.1854 & 0.2155 & 0.208 & 0.2166 \\
\hline \multicolumn{5}{|c|}{ Respondents' assessment of their own experience of using the ways of obtaining foreign academic activity } \\
\hline plan to go abroad (again) & 0.1902 & 0.2113 & 0.2877 & 0.2483 \\
\hline temporarily work abroad & 0.2798 & 0.2197 & 0.1793 & 0.1619 \\
\hline continue your studies abroad & 0.3001 & 0.2803 & 0.2037 & 0.091 \\
\hline get / confirm a degree abroad & 0.201 & 0.1678 & 2.081 & 0.2008 \\
\hline make a scientific career abroad & 0.2901 & 0.3087 & 0.3002 & 0.2195 \\
\hline
\end{tabular}

* Correlations found to be statistically significant 
Table 2: Spearman's rank correlation coefficient between some answer options and groups of participants by age

\begin{tabular}{|c|c|c|c|c|c|}
\hline & \multicolumn{4}{|c|}{ Age, years } & \multirow[b]{2}{*}{ over 60} \\
\hline & $18-30$ & $30-40$ & $40-50$ & $50-60$ & \\
\hline \multicolumn{6}{|c|}{ Respondents' assessment of their own experience of foreign academic activity } \\
\hline plan to go abroad (again) & 0.1897 & 0.2817 & 0.2288 & 0.3388 & 0.1782 \\
\hline temporarily work abroad & 0.2217 & 0.3001 & 0.2502 & 0.3116 & 0.09 \\
\hline continue your studies abroad & 0.2191 & 0.2095 & 0.3107 & 0.3006 & 0.1492 \\
\hline get / confirm a degree abroad & 0.2417 & 0.2773 & 0.278 & 0.2357 & 0.1674 \\
\hline make a scientific career abroad & 0.3001 & 0.2816 & 0.2487 & 0.2186 & 0.0027 \\
\hline \multicolumn{6}{|c|}{ Assessment of the respondents' own intentions regarding foreign academic activity } \\
\hline participation in international programs & 0.3217 & 0.298 & 0.2247 & 0.2306 & 0.1608 \\
\hline independent travel abroad & 0.3107 & 0.2923 & 0.1893 & 0.2144 & 0.1809 \\
\hline commercial work abroad in the specialty & 0.3204 & 0.2236 & $0.3912^{*}$ & 0.2134 & 0.1788 \\
\hline using your own academic connections & 0.109 & 0.2894 & 0.2654 & $0.4102 *$ & $0.6781^{*}$ \\
\hline experience of multiple temporary stay abroad & 0.31012 & 0.1999 & 0.2419 & 0.1236 & 0.2672 \\
\hline \multicolumn{6}{|c|}{ Part of the respondents with real experience in foreign academic activities } \\
\hline participation in international programs & 0.2799 & 0.2809 & 0.3102 & 0.3028 & 0.3107 \\
\hline independent travel abroad & 0.3113 & 0.3201 & 0.3214 & 0.2889 & 0.2204 \\
\hline commercial work abroad in the specialty & 0.3216 & 0.3099 & $0.4119 *$ & 0.2194 & 0.1819 \\
\hline using your own academic connections & 0.3003 & 0.2763 & 0.2297 & $0.3587^{*}$ & $0.5817^{*}$ \\
\hline experience of multiple temporary stay abroad & 0.3076 & 0.1419 & 0.1926 & 0.1765 & 0.2116 \\
\hline \multicolumn{6}{|c|}{ Part of the respondents using way to get foreign academic activities } \\
\hline participation in international programs & 0.2413 & 0.1871 & 0.2109 & 0.1632 & 0.098 \\
\hline independent travel abroad & 0.2903 & 0.2142 & 0.2103 & 0.2117 & 0.0175 \\
\hline commercial work abroad in the specialty & 0.3316 & 0.1984 & 0.1977 & 0.1816 & 0.1022 \\
\hline using your own academic connections & 0.3128 & 0.1877 & 0.1706 & 0.1634 & 0.1238 \\
\hline experience of multiple temporary stay abroad & 0.3097 & 0.1693 & 0.2209 & 0.1092 & 0.1678 \\
\hline \multicolumn{6}{|c|}{ Respondents' assessment of their own experience of using the ways of obtaining foreign academic activity } \\
\hline plan to go abroad (again) & 0.1432 & 0.2419 & 0.1903 & 0.2107 & 0.007 \\
\hline temporarily work abroad & 0.2612 & 0.2714 & 0.0987 & 0.1668 & 0.0613 \\
\hline continue your studies abroad & 0.1676 & 0.1786 & 0.2463 & 0.1897 & 0.0417 \\
\hline get / confirm a degree abroad & 0.1896 & 0.1923 & 0.2833 & 0.2108 & 0.1092 \\
\hline make a scientific career abroad & 0.2151 & 0.2087 & 0.6155 & 0.1432 & 0.007 \\
\hline
\end{tabular}

* Correlations found to be statistically significant 
Table 3: Spearman's rank correlation coefficient between some answer options and groups of participants by specialization (natural science or humanitarian)

\begin{tabular}{|c|c|c|c|c|}
\hline & \multicolumn{2}{|l|}{ students } & \multicolumn{2}{|l|}{ teachers } \\
\hline & $\begin{array}{l}\text { natural } \\
\text { science }\end{array}$ & $\begin{array}{l}\text { humanitarian } \\
\text { science }\end{array}$ & $\begin{array}{l}\text { natural } \\
\text { science }\end{array}$ & $\begin{array}{l}\text { humanitarian } \\
\text { science }\end{array}$ \\
\hline \multicolumn{5}{|c|}{ Respondents' assessment of their own experience of foreign academic activity } \\
\hline plan to go abroad (again) & 0.3111 & 0.1232 & 0.2891 & 0.2998 \\
\hline temporarily work abroad & 0.2819 & 0.2668 & 0.299 & 0.2674 \\
\hline continue your studies abroad & 0.1564 & 0.1607 & 0.2961 & 0.091 \\
\hline get / confirm a degree abroad & 0.2708 & 0.1617 & 0.2092 & 0.1933 \\
\hline make a scientific career abroad & 0.2109 & 0.2783 & 0.1645 & 0.2451 \\
\hline \multicolumn{5}{|c|}{ Assessment of the respondents' own intentions regarding foreign academic activity } \\
\hline $\begin{array}{l}\text { participation in international } \\
\text { programs }\end{array}$ & 0.2708 & 0.2102 & 0.2718 & 0.2273 \\
\hline independent travel abroad & 0.2216 & 0.209 & 0.2677 & 0.2324 \\
\hline $\begin{array}{l}\text { commercial work abroad in the } \\
\text { specialty }\end{array}$ & 0.1408 & 0.3001 & 0.193 & 0.1238 \\
\hline $\begin{array}{l}\text { using your own academic } \\
\text { connections }\end{array}$ & 0.1891 & 0.298 & 0.1673 & 0.2164 \\
\hline $\begin{array}{l}\text { experience of multiple temporary } \\
\text { stay abroad }\end{array}$ & 0.2019 & 0.2907 & 0.1866 & 0.1906 \\
\hline \multicolumn{5}{|c|}{ Part of the respondents with real experience in foreign academic activities } \\
\hline $\begin{array}{l}\text { participation in international } \\
\text { programs }\end{array}$ & $0.592^{*}$ & 0.319 & $0.5415^{*}$ & 0.3228 \\
\hline independent travel abroad & 0.091 & 0.1916 & 0.2816 & 0.1789 \\
\hline $\begin{array}{l}\text { commercial work abroad in the } \\
\text { specialty }\end{array}$ & 0.3328 & 0.3391 & 0.3209 & 0.2891 \\
\hline $\begin{array}{l}\text { using your own academic } \\
\text { connections }\end{array}$ & 0.2816 & 0.2367 & 0.2859 & 0.2579 \\
\hline $\begin{array}{l}\text { experience of multiple temporary } \\
\text { stay abroad }\end{array}$ & 0.1903 & 0.2091 & 0.198 & 0.2271 \\
\hline \multicolumn{5}{|c|}{ Part of the respondents using way to get foreign academic activities } \\
\hline $\begin{array}{l}\text { participation in international } \\
\text { programs }\end{array}$ & 0.235 & 0.1922 & 0.1981 & 0.1709 \\
\hline independent travel abroad & 0.2461 & 0.2369 & 0.1974 & 0.1596 \\
\hline $\begin{array}{l}\text { commercial work abroad in the } \\
\text { specialty }\end{array}$ & 0.2616 & 0.1708 & 0.2534 & 0.0179 \\
\hline $\begin{array}{l}\text { using your own academic } \\
\text { connections }\end{array}$ & 0.3112 & 0.2971 & 0.3103 & 0.2219 \\
\hline $\begin{array}{l}\text { experience of multiple temporary } \\
\text { stay abroad }\end{array}$ & 0.2806 & 0.2629 & 0.3106 & 0.2919 \\
\hline \multicolumn{5}{|c|}{ Respondents' assessment of their own experience of using the ways of obtaining foreign academic activity } \\
\hline plan to go abroad (again) & 0.2271 & 0.3113 & 0.3214 & 0.2809 \\
\hline temporarily work abroad & $0.7102^{*}$ & 0.2748 & $0.6891^{*}$ & 0.2809 \\
\hline continue your studies abroad & 0.2791 & 0.2419 & 0.2781 & 0.2853 \\
\hline get / confirm a degree abroad & 0.2817 & 0.3022 & 0.2419 & 0.1771 \\
\hline make a scientific career abroad & 0.312 & 0.2456 & 0.1904 & 0.2913 \\
\hline
\end{tabular}

* Correlations found to be statistically significant 